\title{
THE CRITICAL ROLE OF BRAND LOVE IN CLOTHING BRANDS
}

\section{DOI: 10.17261/Pressacademia.201519963}

\author{
Merve Ulku TURGUT ${ }^{1}$, Beyza GULTEKIN ${ }^{2}$ \\ ${ }^{1}$ Ufuk University. E-mail: muturgut@gmail.com \\ ${ }^{2}$ Hacettepe University. E-mail: beyza@hacettepe.edu.tr
}

\author{
Keywords: \\ Brand love, \\ brand trust, \\ resistance to negative information, \\ intention to repurchase
}

\section{JEL Classification:}

M310

\begin{abstract}
This paper aims to explore brand love in the context of brand trust, resistance to negative information and intention to repurchase in the clothing brand context. Based on a sample of 400 respondents, simple regression and multiple regression analyses were conducted to analyse direct effects and bootstrapping analyses were run to examine mediating roles. The analyses indicate a significant positive effect of brand trust on brand love, resistance to negative information, and intention to repurchase. In addition, brand love is confirmed to positively influence resistance to negative information and intention to repurchase. Concerning mediating roles, brand love is the mediator of the relation between brand trust and resistance to negative information and intention to repurchase. These results provide guidance to managers of clothing brands by disclosing the importance of brand love and brand trust. Accordingly, to have a brand customers love, managers should invest in gaining consumers' trust. Such valuable relationships eventually facilitate consumer resistance against negative information and intention to repurchase.
\end{abstract}

\section{INTRODUCTION}

Brands play a considerable role in consumers' decision-making processes (Fischer, Völckner and Sattler, 2010). Consumers may pay premium prices for some brands and continue to prefer these brands in time (Fischer et al., 2010). From the firms' perspective, since obtaining new consumers is more costly than maintaining current ones, firms depend on their brands to retain their consumers (Stone, Woodcock and Wilson, 1996). Furthermore, to keep their consumers, firms establish deep, long-term relations with consumers (Bennett, 1996; Acton, 1998). However, seriously high numbers of consumers obstruct firms' one-to-one relations with them (Lau and Lee, 1999), which is why firms need brands to maintain relationships with their consumers (Zboja and Voorhees, 2006). Therefore, brands would be used not only to survive in the market for a long time (Delgado-Ballester and Munuera-Alemán, 2005; Fischer et al., 2010) but also to have longterm relationships with their customers (Zboja and Voorhees, 2006). 
In consumer-brand relationships, brand love is one of the deepest and most intense relationship types (Albert, Matthews-Lefevbre, Merunka and Valette-Florence, 2007). The concept of brand love therefore receives remarkable attention, both theoretically and practically (Albert et al., 2007). According to Fournier (1998), the core elements of consumer-brand relationships are love and passion. Furthermore, Kevin Roberts (2005), CEO at Saatchi \& Saatchi, states that firms should focus on the brand love concept to have long-term relationships and eventually create brand loyalty. As a result, companies follow a consumer relationship strategy to turn their brand into a Lovemark. When a brand becomes a Lovemark, its company is differentiated in the market and gains a competitive advantage.

Some studies examine brand love based on interpersonal love (Carroll and Ahuvia, 2006). According to Batra, Ahuvia and Bagozzi (2012) even though interpersonal love theories are helpful in explaining the brand love concept, deeper research is necessary to better understand this concept. Moreover, although brand love is an essential type of consumerbrand relation in consumer behaviour, there is little research on this concept (Carroll and Ahuvia, 2006; Batra et al., 2012; Sarkar and Murthy, 2012; Shuv-Ami, 2012; Vlachos and Vrechopoulos, 2012; Albert and Merunka, 2013). Therefore, first, this study contributes to the literature by conducting exhaustive research on brand love. To have a good grasp on brand love, its relation to another consumer-brand relation, brand trust, should also be investigated. Trust has an influence on consumers' attitudes about brands (Chaudhuri and Holbrook, 2001). Hence, when consumers trust a brand, they are also willing to establish a love relationship with it (Albert and Merunka, 2013). To better understand the roles of these two concepts, the unique effects of brand love and brand trust dimensions are also investigated.

In addition to the relation between brand trust and brand love, the consequences of brand love need to be analysed. Brand love contributes to consumers' resistance to negative information (Batra et al., 2012) about the brand and repurchase intention (Sarkar and Murthy, 2012; Shuv-Ami, 2012; Vlachos and Vrechopoulos, 2012). Similarly, brand trust seems to increase consumers' repurchase intention (Zboja and Voorhees, 2006; Fang, Chui and Wang, 2011). Moreover, there may be a positive relation between brand trust and resistance to negative information about the brand. However, to the best of the authors' knowledge, such a relation between these two concepts has not yet been justified. Therefore, this study contributes to the literature by analysing this relation. In addition, there are few studies about consumers' resistance to negative information (e.g. Ahluvalia, Burnkrant and Unnava, 2000; Eisingerich, Rubera, Seifert and Bhardwaj, 2011). Again, to the best of our knowledge, the marketing literature does not have a model involving brand love, brand trust, resistance to negative information, and intention to repurchase. To summarize, this model will fill a remarkable gap in the literature.

Accordingly, this article aims to explore the relation between brand love and brand trust, resistance to negative information, and intention to repurchase in clothing brands. In doing so, first, the related literature is reviewed. Then, the method, analyses, and results are presented and the findings are discussed. Finally, limitations and directions for future researchers and managers are presented. 


\section{THEORETICAL BACKGROUND AND RESEARCH HYPOTHESES}

\subsection{Brand Trust}

Trust is the topic of many different research areas, such as marketing, management, and economics, (Doney and Cannon, 1997), such that this construct has a very vast literature. According to Rousseau, Sitkin, Burt and Camerer (1998), trust is a willingness to be vulnerable to others' intentions and behaviours that is expected to be positive. Similarly, trust is one party's willingness to be vulnerable to another's behaviours (Mayer, Davis and Schoorman, 1995).

In the formation of trust, various concepts - namely, risk, ambiguity, the amount of information, and mutual interdependence - are critical. Trust involves risk taking to a certain extent (Mayer et al., 1995). Grabner-Kräuter and Kaluscha (2003) claim that when there is full transparency, there is no need to trust anyone. The truster's knowledge level about the situation is also an important point (McAllister, 1995). When people have an excess of knowledge or a lack of knowledge, there is no need for trust. Thus, an average amount of knowledge is required for trust. Another facet of trust is mutual interdependence (Rousseau et al., 1998). Mutual need and interest shape trust.

High competition and excessive numbers of consumers makes it difficult to establish relationships with consumers (Lau and Lee, 1999), so companies obtain help from their brands. This leads companies to use brands to develop trusting relationships with their customers (Zboja and Voorhees, 2006). Delgado-Ballester and Munuera-Alemán (2001, p. 1242) define brand trust as 'a feeling of security held by the consumer that the brand will meet his/her consumption expectations'. According to Chaudhuri and Holbrook (2001), brand trust occurs when consumers believe the brand keeps its promises. Brand trust has two dimensions: reliability and intention (Delgado-Ballester and MunueraAlemán, 2001). Reliability concerns the brand's skills and capabilities to meet consumers' needs and desires (Delgado-Ballester, Munuera-Aleman and Yague-Guillen, 2003; Sung and Kim, 2010). The latter dimension states that brands should take into account consumers' interests and problems instead of behaving opportunistically (Doney and Cannon, 1997; Delgado-Ballester et al., 2003).

Brand trust has many advantages for companies. It is said that trust is the cornerstone of the relationships between consumers and brands (Morgan and Hunt, 1994; Garbarino and Johnson, 1999; Delgado-Ballester et al., 2003; Elliott and Yannopoulou, 2007). In addition, consumers are more prone to buy brands they trust (Chatterjee and Chaudhuri, 2005). Similarly, many empirical studies prove the positive impact of brand trust on loyalty (Lau and Lee, 1999; Chaudhuri and Holbrook, 2001; Delgado-Ballester et al., 2003; DelgadoBallester and Munuera-Alemán, 2005; Sichtmann, 2007; Matzler, Grabner-Kräuter and Bidmon, 2008; Laroche, Habibi, Richard and Sankaranarayanan, 2012). Besides, brand trust contributes to consumers' positive word of mouth (Sichtmann, 2007). Lastly, Robert Bosch, founder of Bosch, states he 'would rather lose money than trust', emphasizing the importance of trust relative to material things. 


\subsection{Brand Love}

Among all consumer-brand relationships in the literature, brand love seems to be the most recent and popular concept (Ahuvia, 2005; Carroll and Ahuvia, 2006; Batra et al., 2012). Carroll and Ahuvia (2006) define brand love construct as 'the degree of passionate emotional attachment a satisfied consumer has for a particular trade name' (p. 81). While some studies (Carroll and Ahuvia, 2006) consider brand love an emotion, others (Keh, Pang and Peng, 2007; Batra et al., 2012) regard this construct as a relationship. A love relationship, compared to the emotion of love, lasts longer. Brand love relationships between consumers and brands include long-term cognitive, emotional, and behavioural terms (Batra et al., 2012).

Many studies categorize brand love into various dimensions. According to Carroll and Ahuvia (2006), brand love is a one-dimensional construct; however, Kamat and Parulekar (2007) posit that brand love concept has five dimensions: friendship, contentment, admiration, commitment, and yearning. Albert Merunka and Valette-Florence (2008) propose 11 dimensions for brand love: passion, duration, self-congruity, dreams, memories, pleasure, attraction, uniqueness, beauty, trust, and declaration. Passion-driven behaviour, self-brand integration, positive emotional connection, long-term relationship, anticipated separation distress, and attitude valence are the six brand love dimensions presented by Bagozzi, Batra and Ahuvia (2013). Further studies are needed to better clarify the dimensions of the brand love concept. This research provides a helpful contribution to the literature and to brand managers by identifying brand love factors in the context of clothing.

Some studies (Shimp and Madden, 1988; Whang, Allen, Sahoury and Zhang, 2004) examine the brand love based on interpersonal love theories. Shimp and Madden (1988) explain the relationships formed between consumers and consumption goods on the basis of Sternberg's (1986) triangular Theory of Love. On the other hand, Batra et al. (2012) states that Triangular Theory of Love is insufficient for understanding brand love in detail. With respect to interpersonal love, brand love is one sided (Shimp and Madden, 1988; Whang et al., 2004; Batra et al., 2012). In addition, the love relationships between consumers and brands are less important than interpersonal love (Batra et al., 2012).

Fetscherin and Conway-Dato-on (2012) claim brand love to be analogous to a parasocial relationship. In parasocial relationships, while one party has clear information about the other one, the other party has no such knowledge. Similarly, in love relationships between consumers and brands, brands are not aware of the consumers' love. Thus, parasocial love better explains brand love (Fetscherin and Conway-Dato-on, 2010). In addition, consumers interpret their relationships with brands and with other people in two different regions of brain, proving the difference between these two relationships (Yoon, Allen, Sahoury and Zhang, 2006).

Firms want their brands to be Lovemarks (Roberts, 2005). When a brand deserves a Lovemark title, it may differ from other brands and obtain a competitive advantage in the market (Roberts, 2005). Brand love is also necessary to understand and segment consumer behaviours (Pang, Keh and Peng, 2009). Brand love has a positive impact on consumers' intention to repurchase (Keh et al., 2007; Bergkvist and Bech-Larsen, 2010; 
Batra et al., 2012; Rossiter, 2012; Shuv-Ami, 2012). Similarly, brand love positively influences brand loyalty (Carroll and Ahuvia, 2006; Bergkvist and Bech-Larsen, 2010).

Brand love thus helps companies have long-term relationships with their customers (Fournier, 1998). Furthermore, when consumers love a brand, they will visit the brand's webpage (Bergkvist and Bech-Larsen, 2010). Another benefit of brand love is related to positive word of mouth. When consumers love a brand, they tend to mention its advantages and recommend it to relatives, friends, family, and so forth (Carroll and Ahuvia, 2006; Batra et al., 2012; Bergkvist and Bech-Larsen, 2010; Correia Loureiro and Kaufmann 2012; Rossiter, 2012; Shuv-Ami, 2012; Yasin and Shamim, 2013).

In interpersonal relationships, trust leads to love between people (Hazan and Shaver, 1987; Shaver, Schwartz, Kirson and O'connor, 1987). Similarly, in consumer-brand relations studies (Patwardhan and Balasubramanian, 2011; Albert and Merunka, 2013) indicate that consumers who trust a brand can also come to love it. Thus, we have the following hypothesis.

H1. Brand trust has a positive influence on brand love.

\subsection{Resistance to Negative Information}

During consumers' purchase decision processes, they need information about the firm and about their products or brands (Herr, Kardes and Kim, 1991). The gathered information will have an impact on consumers' attitudes and behaviours (Brown and Reingen, 1987). However, positive and negative information have different levels of influence on consumers (Fiske, 1980). Negative information has a greater impact on consumers' thoughts and behaviours about firms/brands than positive information, which is known as the negativity effect (Skowronski and Carlston, 1998). According to Pullig, Netemeyer and Biswas (2006), negative information is related to performance or value. Researchers state that performance-related negative information arises from a firm's functional activities. Problems with ironing a clothing firm's skirts and an airline company selling the same seat to more than one person are examples of performance-related negative information. Value-related negative information involves social or ethical considerations (Pullig et al., 2006). An e-mail provider's sharing users' personal information and a firm's financial assistance of terrorist organizations are examples of value-related negative information. Negative information about firms and their products or brands negatively affects financial returns (Luo, 2007, 2009). In addition, it decreases company reputation and employee morale and motivation (Kimmel and Audrain-Pontevia, 2010).

Resistance to negative information is the degree to which consumers do not let negative information negatively influence their evaluations about the firm (Eisingerich et al., 2011). Attitudes against negative information can differ among consumers. Certain consumers show resistance to negative information (Eisingerich et al., 2011). The extent of the resistance to negative information is determined by certain constructs. Specifically, satisfied customers are more resistant to negative information about the services they received (Eisingerich et al., 2011). Commitment to a firm also helps consumers to deny such negativity (Ahluwalia et al., 2000). Additionally, the more social responsibility a firm bears, the more consumers will resist pertinent negative information (Eisingerich et al., 
2011). In addition, strong consumer-brand relationships positively contribute to consumer resistance to negative information (Eisingerich et al., 2011).

Based on this, brand trust, the cornerstone of strong consumer-brand relationships (Morgan and Hunt, 1994), may increase consumer resistance to negative information. Therefore, we propose the following hypothesis:

H2. Brand trust has a positive influence on resistance to negative information.

When identification - one of the six dimensions of brand love (Batra et al., 2012) - takes place between a customer and a brand, the customer's resistance to negative information increases (Bhattacharya and Sen, 2003). In addition, resistance to negative information is positively affected by satisfaction (Eisingerich et al., 2011) and attachment (Ahluwalia et al., 2000). Since brand love is the extent of a 'satisfied consumer's passionate emotional attachment' (Carroll and Ahuvia, 2006, p. 81) for a brand, the brand love relationship between customers and brands increases consumers' resistance to negative information (Batra et al., 2012). As a result, we have the following hypothesis:

H3. Brand love has a positive influence on resistance to negative information.

\subsection{Intention to Repurchase}

A repurchase is a consumer buying a particular product or brand more than once (Curtis, 2009). Intention is the extent of a person's desires and efforts to perform an action (Ajzen, 1991). Thus, the intention to repurchase construct can be defined as 'the individual's judgment about buying again a designated service from the same company, taking into account his or her current situation and likely circumstances' (Hellier, Geursen, Carr and Rickard, 2003, p. 1764). Since, customer acquisition is many times more costly than customer retention (Stone et al., 1996), intention to repurchase a brand is worthy of future consumer/firm relationships (Chung and Lee, 2003).

Trust decreases consumers' risk perception about a product/brand (Pavlou, 2003). A consumer's intention to repurchase a low-risk product/brand is higher than the intention to repurchase a high-risk one (Pavlou, 2003). In addition, Herbst, Hannah and Allan (2013) state that trust should be formed between a consumer and a brand prior to the consumer's purchase of the brand. Accordingly, trust is one of the critical elements considered in the selection of a brand among alternatives, as indicated by empirical studies (Zboja and Voorhees, 2006; Fang et al., 2011). Thus, this study claims that if a consumer trusts a brand, the consumer's intention to repurchase it raises. Thus, we propose the following hypothesis:

H4. Brand trust has a positive influence on intention to repurchase.

The brand love literature posits that brand love positively influences consumer loyalty (Carroll and Ahuvia, 2006; Bergkvist and Bech-Larsen, 2010; Batra et al., 2012; Correia Loureiro and Kaufmann, 2012). Similarly, recent studies show that intention to repurchase is the consequence of brand love (Sarkar and Murthy, 2012; Shuv-Ami, 2012; Vlachos and Vrechopoulos, 2012). Based on the above discussions, we propose that intention to repurchase is the consequence of a brand love relationship, as follows. Accordingly:

$\mathrm{H} 5$. Brand love has a positive influence on intention to repurchase. 
Zboja and Voorhees (2006) and Fang et al. (2011) state that when consumers trust a brand, they will deny negativity about the brand. Consumers' trust towards a brand also promotes their love for it (Patwardhan and Balasubramanian, 2011; Albert and Merunka, 2013). Additionally, Batra et al. (2012) find a positive effect of brand love on consumers' resistance to negative information. On the basis of these studies, it is posited that love towards a brand mediates the relation between consumer trust in that brand and resistance to negative information about the brand. As a result, we arrive at the following hypothesis.

H6. Brand love mediates the relation between brand trust and resistance to negative information.

In today's market conditions, trust is not sufficient to convince consumers to buy a particular brand over time (Roberts, 2005). Consumers' intention to repurchase depends on the degree of love they have for the brand (Roberts, 2005). Zboja and Voorhees (2006) and Fang et al. (2011) note a positive association between trust and intention to repurchase, as well as a positive association of brand love with intention to repurchase. Thus, one should investigate whether the relation between brand trust and intention to repurchase is mediated by brand love. Accordingly, we propose the following hypothesis.

H7. Brand love mediates the relation between brand trust and intention to repurchase.

Figure 1 presents the research framework in light of the literature and the proposed hypotheses. 


\section{Figure 1: The Hypothesized Model}
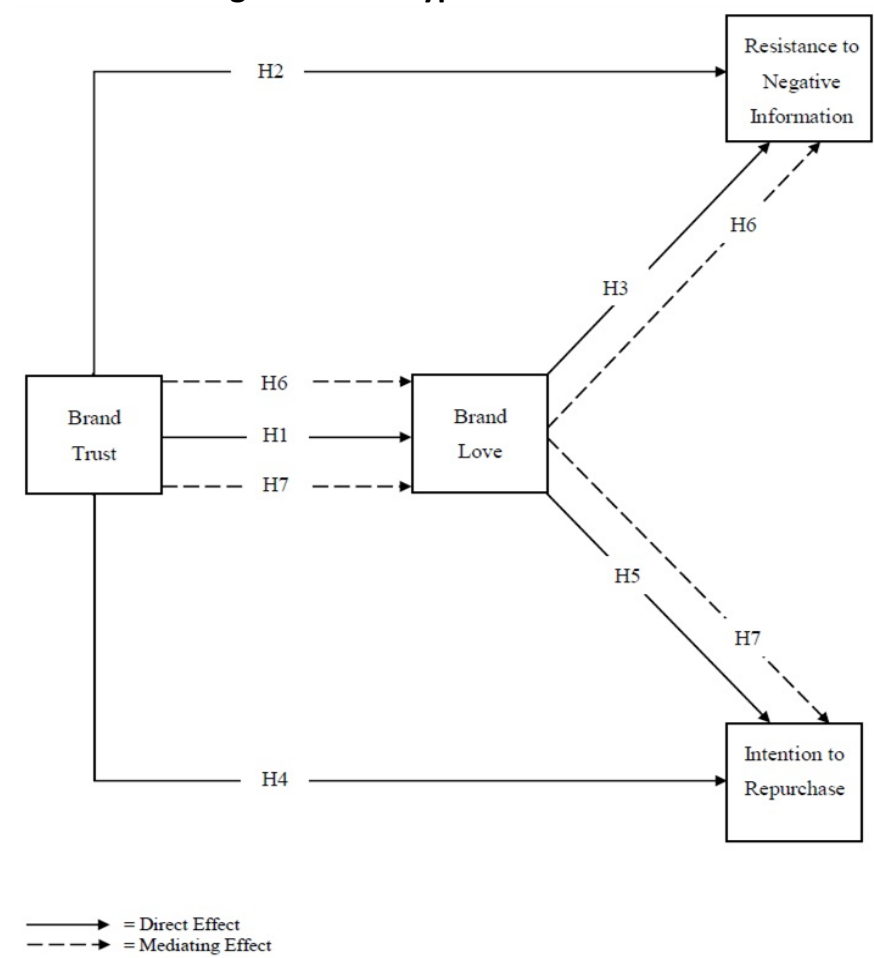

\section{METHODOLOGY}

\subsection{Product Selection}

Exploratory research was conducted on deciding on the product. A total of 30 participants were asked for the first three brands that came to mind. Of the 90 stated brands, 37, constituting the great majority, are from clothing industry, with electronics brands (13) and food/beverage brands (13) the next two most stated. Thus, clothing was selected as the product in this study. The clothing industry plays a valuable role in the Turkish economy. Turkey is the seventh biggest clothing exporter in the world and the clothing industry constitutes $7 \%$ of its gross domestic product (Republic of Turkey Ministry of Economy, 2014). Additionally, 5.4\% of household expenditures are clothing (Turkish Statistical Institute, 2013). Thus, this research will contribute to the development of the clothing industry.

\subsection{Data Collection and Measures}

A questionnaire was used for the survey. The convenience sampling method was used to collect data from 400 participants (Turgut, 2014). A total of $57.2 \%$ of the respondents were female and the majority (67.2\%) ranged in age from 18 to 25 years; $69.5 \%$ were middle-income respondents and $68 \%$ of them held a bachelor's degree. Instead of a specific clothing brand or brands, the questionnaire asked respondents to answer based on clothing brands they favoured and had bought before. The first reason behind this was 
to have a broad, random list of brands. The second reason was to avoid influencing the participants' choices.

The measurements for brand love were adapted from those of Bagozzi et al. (2013), for a total of 27 items. The brand trust scale of Bagozzi et al. (2013) was also modified to comprise 10 items. Resistance to negative information was adapted from Eisingerich et al. (2010) and was measured by two items. Intention to repurchase was assessed by three items adapted from Parasuraman Zeithaml and Malhotra (2005) and Pavlou and Fygenson (2006). Except for two items of brand love, which were measured by semantic differentiation, all the items were measured by five-point Likert-type scales with the anchors strongly disagree (one) and strongly agree (five). A complete list of the measurement items is provided in the Appendix.

\subsection{Analyses and Results}

Exploratory factor analysis (EFA) with principal component analysis using varimax rotation was applied to the brand trust scale to examine its factor structure. Barlett's test of sphericity and the Keiser-Meyer-Olkin (KMO) value of sampling adequacy indicate no collinearity between the items and an adequate sample size for analysis (Barlett's test significant at $p<0.001, \mathrm{KMO}=0.886)$. Accordingly, two factors were determined to explain $66.68 \%$ of the variance of the total set of variables. Based on the literature (Doney and Cannon, 1997; Delgado-Ballester and Munuera-Alemán, 2001), these two factors were called credibility (BT1, BT2, BT3, BT4, and BT5) and benevolence (BT6, B7, BT8, BT9, and BT10). Table 1 provides the results from the EFA of the brand trust facets.

Table 1: Reliability values, factor loadings, and explained variance values for the brand trust scale

\begin{tabular}{|c|c|c|}
\hline \multirow{2}{*}{ Items } & \multicolumn{2}{|c|}{ Factors } \\
\hline & 1 & 2 \\
\hline \multicolumn{3}{|l|}{ Credibility (Cronbach's Alpha: 0.82) } \\
\hline BT1. I trust this brand. & 0.850 & \\
\hline BT2. This brand meets my expectations. & 0.805 & \\
\hline BT3. I feel confidence in this brand. & 0.692 & \\
\hline BT4. This is a brand name that never disappoints me. & 0.619 & \\
\hline BT5. This brand name guarantees satisfaction. & 0.529 & \\
\hline \multicolumn{3}{|l|}{ Benevolence (Cronbach's Alpha: 0.90) } \\
\hline $\begin{array}{l}\text { BT6. If I had a complaint related to this brand or one of their } \\
\text { products, they would be honest in addressing my concerns. }\end{array}$ & & 0.854 \\
\hline $\begin{array}{l}\text { BT7. If I had a complaint related to this brand or one of their } \\
\text { products, they would be sincere in addressing my concerns. }\end{array}$ & & 0.886 \\
\hline $\begin{array}{l}\text { BT8. If I had a problem related to this brand or one of their } \\
\text { products, I could rely on it to solve it. }\end{array}$ & & 0.852 \\
\hline BT9. This brand would make every effort to satisfy me. & & 0.674 \\
\hline $\begin{array}{l}\text { BT10. If I had a problem related to this brand or one of their } \\
\text { products, which could not readily be resolved, it would } \\
\text { compensate me in some way for the problem. }\end{array}$ & & 0.764 \\
\hline Eigenvalue & 5.37 & 1.29 \\
\hline
\end{tabular}


Explained Variance

$38.13 \% \quad 28.54 \%$

Total Explained Variance

$38.13 \% \quad 66.68 \%$

Confirmatory factor analysis was performed to determine the appropriateness of this twofactor solution and the distribution of the scale items. Based on the modification index suggestions, error covariances between BT1 and BT2 and between BT6 and BT7 were described. Subsequently, the model was found to fit well with the data $\left(\chi^{2} / \mathrm{df}=3.17\right.$, $\mathrm{RMSEA}=0.07, \mathrm{GFI}=0.95$, and $\mathrm{CFI}=0.97$ ). Reliability analyses were conducted to ensure the internal consistency of the dimensions of brand trust. Accordingly, brand trust dimensions have high internal consistency (Table 1).

Since brand love is quite a new concept in the literature, EFA was conducted to clarify the dimensions of this concept. Principal component analysis with varimax rotation was used for the EFA. Bartlett's test of sphericity was significant $(p<0.001$, KMO measure of sampling adequacy 0.884 ) and showed no collinearity between the items and adequate sample size for the analysis. The results show high cross-loading for BL18 and BL19 (see the Appendix 1). Thus, after these two items were excluded, the EFA was run with the remaining 25 items. Accordingly, six factors were determined, called life meaning, selfbrand integration, long-lasting connection, passion-driven behaviour, anticipated separation distress, and attitude valence. Reliability values, factor loadings, and explained variance values of brand love scale are reported in Appendix 2.

Confirmatory factor analysis was conducted to determine whether the six factors suggested by EFA would fit the data. After the modification indices were examined and content analysis was performed on the items, error covariances between the items were added based on the modification indices (BL1-BL2, BL6-BL7, BL8-BL9, BL10-BL11, BL12BL13, BL14-BL15, BL16-BL17, and BL20-BL21). Therefore, after modification, the sixfactor model fits the data $\left(\chi^{2} / \mathrm{df}=2.63, \mathrm{RMSEA}=0.06, \mathrm{GFI}=0.88, \mathrm{CFI}=0.93\right)$. Reliability analyses were conducted to ensure the internal consistency of the research constructs. As seen in Table 1, brand love's dimensions' Cronbach's alpha values have high internal consistency.

Hypotheses for direct relations were tested by regression analysis. Table 3 reports the reliability values, descriptive statistics, and correlations for the variables before hypothesis testing. As Table 3 shows, the overall reliabilities of the constructs are also satisfactory

Table 3: Reliability values, descriptive statistics, and correlations for the variables

\begin{tabular}{|c|c|c|c|c|c|c|c|}
\hline Variables & $\begin{array}{l}\text { Cronbach } \\
\text { 's Alpha }\end{array}$ & Mean & $\begin{array}{l}\text { Std. } \\
\text { Dev. }\end{array}$ & 1 & 2 & 3 & 4 \\
\hline 1. Brand Trust & 0.90 & 3.48 & 0.64 & 1 & & & \\
\hline 2. Brand Love & 0.92 & 3.08 & 0.70 & $0.66^{*}$ & 1 & & \\
\hline $\begin{array}{l}\text { 3. Resistance to } \\
\text { Negative Information }\end{array}$ & 0.74 & 3.04 & 0.91 & $0.50^{*}$ & $0.52^{*}$ & 1 & \\
\hline $\begin{array}{l}\text { 4. Intention to } \\
\text { Repurchase }\end{array}$ & 0.82 & 3.19 & 1.03 & $0.53^{*}$ & $0.54^{*}$ & $0.36^{*}$ & 1 \\
\hline
\end{tabular}


${ }^{*} p<0.01$

To obtain a clear understanding about brand love, the relation between brand love and the other constructs - namely, brand trust, resistance to negative information, and intention to repurchase - is first analysed at the construct level (overall brand love and overall brand trust) and then at the dimensional level (brand love dimensions and brand trust dimensions). As Albert and Merunka (2013) state, dimensions of brand trust and brand love can be either affective or cognitive. This means the unique roles of the dimensions need to be analysed. Such an approach is therefore also more informative about the specific roles of brand love and brand trust.

Accordingly, regression analyses were performed to test the direct impact of brand trust on brand love. The results show that brand trust $(\beta=0.66 ; p<0.001)$ significantly and positively contribute to brand love $\left(\mathrm{R}^{2}=0.435 ; \mathrm{F}=306.799 ; p<0.001\right)$. This means brand trust plays a strong role in developing consumer love towards a brand. Hence, $\mathrm{H} 1$ is supported. Regarding the dimensions, credibility $(\beta=0.501 ; p<0.001)$ and benevolence $(\beta$ $=0.231 ; p<0.001)$ both have significant and positive impacts on brand love $\left(\left(R^{2}=0.448 ; F\right.\right.$ $=162.839 ; p<0.001)$.

Multiple regression analysis was performed to test the influences of brand trust and brand love on resistance to negative information. As a result, brand trust $(\beta=0.286 ; p<0.001)$ and brand love $(\beta=0.339 ; p<0.001)$ both have significant positive impacts on resistance to negative information $\left(\mathrm{R}^{2}=0.321 ; \mathrm{F}=95.274 ; p<0.001\right)$. So, $\mathrm{H} 2$ and $\mathrm{H} 3$ are supported.

Concerning dimensions, the benevolence dimension $(\beta=0.227 ; p<0.001)$ of brand trust and life meaning and the value given dimension of brand love $(\beta=0.258 ; p<0.001$ ) influence consumers' resistance to negative information $\left(R^{2}=0.333 ; F=25.881 ; p<\right.$ 0.001 ). On the other hand, the credibility dimension of brand trust and self-brand integration, long-lasting connection, passion-driven behaviour, anticipated separation distress, and the attitude valence dimension of brand love do not have significant impacts on resistance to negative information $(p>0.05)$.

Multiple regression analysis was conducted to test the impacts of brand trust and brand love on intention to repurchase. Accordingly, brand trust $(\beta=0.321 ; p<0.001)$ and brand love $(\beta=0.328 ; p<0.001)$ significantly and positively influence intention to repurchase $\left(R^{2}\right.$ $=0.347 ; \mathrm{F}=106.859 ; p<0.001)$. Therefore, $\mathrm{H} 4$ and $\mathrm{H} 5$ are supported. Both credibility $(\beta=$ $0.149 ; p<0.05)$ and benevolence $(\beta=0.160 ; p<0.05)$ positively affect intention to repurchase; the passion-driven behaviour $(\beta=0.199 ; p<0.001)$ and attitude valence $(\beta=$ $0.116 ; p<0.05)$ dimensions of brand love positively influence consumers' intention to repurchase $\left(R^{2}=0.353 ; F=28.256 ; p<0.001\right)$, whereas the brand love dimensions life meaning and value given, self-brand integration, long-lasting connection, and anticipated separation distress do not significantly influence intention to repurchase.

Bootstrapping was carried out to examine the mediating hypotheses, namely, $\mathrm{H} 6$ and $\mathrm{H} 7$. Bootstrapping allows for the testing of mediation (Preacher and Hayes, 2008). As Hayes (2009) recommends, 1,000 resamples were used and these generated a 95\% confidence interval for the mediator. According to Hayes (2009), if zero falls outside this interval, mediation can be said to be present. The mediation model of brand love on the relation 
between brand trust and resistance to negative information is given in Figure 2 . The bootstrapping analysis revealed that the $95 \%$ confidence interval for the magnitude of the mediating effect $(a * b=0.28)$ excluded zero $([0.19,0.39])$. This means brand love has a mediating effect $(p<0.001)$ on the relation between brand trust and resistance to negative information.

Figure 2: Mediating Role of Brand Love in the Relation Between Brand Trust and Resistance to Negative Information

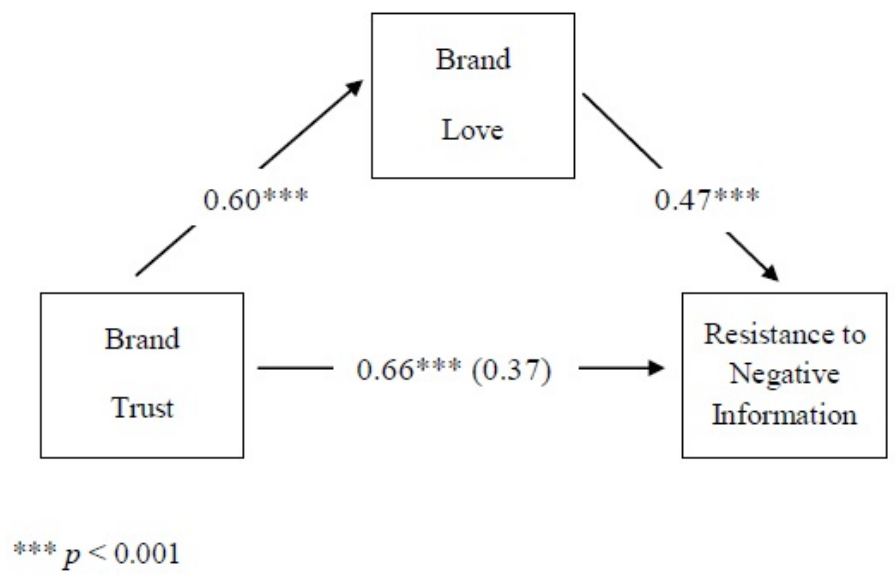

Another proposed mediating role of brand love is that of the relation between brand trust and intention to repurchase. The results for this mediating effect are given in Figure 3. A bootstrapped estimate (Preacher and Hayes, 2008) revealed the mediating effect $(a * b=$ 0.31 ) of brand love on the relation between brand trust and intention to repurchase was significant $([0.22,0.43] ; p<0.001)$. Thus, $\mathrm{H} 7$ is supported.

Figure 3: Mediating Role of Brand Love in the Relation Between Brand Trust and Intention to Repurchase

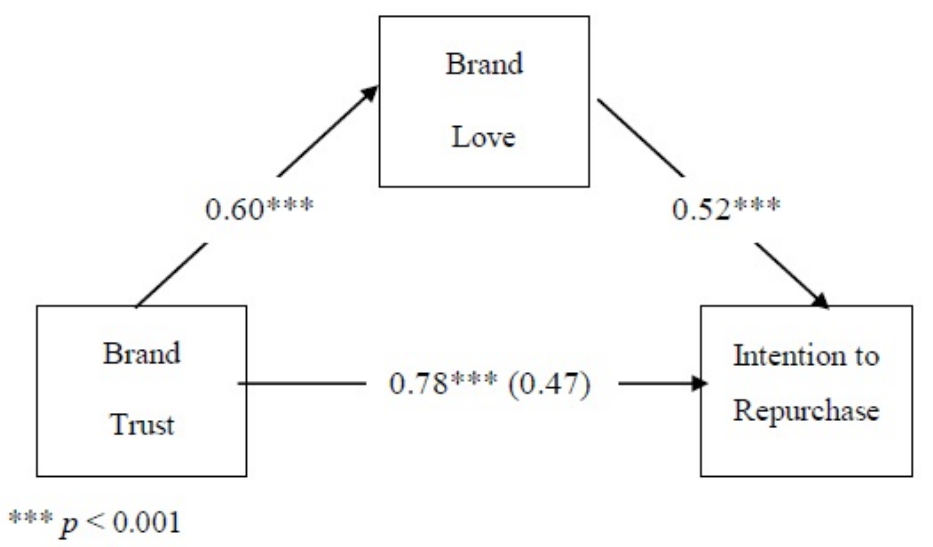

The results of the hypotheses are given in Table 4. Accordingly, all the hypotheses proposed are supported. 
Table 4: Research hypothesis results

\begin{tabular}{ll}
\hline Hypotheses & Results \\
\hline H1. Brand trust has a positive influence on brand love. & $\begin{array}{l}\text { Supported } \\
\text { H2. Brand trust has a positive influence on resistance to negative }\end{array}$ \\
information. & Supported \\
H3. Brand love has a positive influence on resistance to negative & Supported \\
information. & \\
H4. Brand trust has a positive influence on intention to repurchase & Supported \\
H5. Brand love has a positive influence on intention to repurchase. & $\begin{array}{l}\text { Supported } \\
\text { H6. Brand love mediates the relation between brand trust and }\end{array}$ \\
$\begin{array}{l}\text { resistance to negative information. } \\
\text { H7. Brand love mediates the relation between brand trust and intention } \\
\text { to repurchase. }\end{array}$ & Supported \\
\hline
\end{tabular}

\section{CONCLUSION AND IMPLICATIONS}

The purpose of this research is to assess the relation between brand love and brand trust, resistance to negative information, and intention to repurchase in clothing brands. Compared to previous studies about the brand love construct, this study has three obvious originalities. First, to the best of our knowledge, this is the first study to investigate the brand love construct in a clothing brand context.

Therefore, the results of this study reveal several insights about brand love in clothing brands. This study's originality also concerns resistance to negative information. Second, this study focused on the dimensions of brand trust and brand love, investigating their unique effects. Third, this study differs from other brand love studies by investigating its mediating role in the relation between brand trust and resistance to negative information, as well as intention to repurchase. Finally, this study found a notable link between consumers' trust in a brand and resistance to negativity about it.

Brand trust is found to exert a significantly positive effect on brand love. This result is consistent with previous studies (Patwardhan and Balasubramanian, 2011; Albert and Merunka, 2013). Indeed, when consumers rely on a clothing brand's promises and activities, a love relationship is easily established. In addition, consumers' trust in a brand increases their resistance to negative information about the brand. Therefore, consumers resist negativity about brands through their perceived reliance and credibility. Similarly, as Batra et al. (2012) indicate, consumers resist negative information about brands with which they have love relationships. Specifically, the benevolence dimension of brand trust and the life meaning and value given dimensions of brand love influence consumer resistance to negative information.

In addition to these findings, brand trust is found to reinforce consumers' intention to repurchase. This result supports the findings of Zboja and Voorhees (2006) and Fang et al. (2011). Beyond brand trust, based on previous complementary findings (Sarkar and Murthy, 2012; Shuv-Ami, 2012; Vlachos and Vrechopoulos, 2012), the love consumers feel for a brand also enables them to prefer the brand more than once. Regarding dimensions, the brand trust dimensions of credibility and benevolence positively influence intention to 
repurchase. The brand love dimensions of passion-driven behaviour and attitude valence have positive impacts on consumer intention to repurchase.

Besides direct relations, this research investigated the mediating roles of brand love. The results indicate brand trust has positive indirect effects on resistance to negative information and intention to repurchase through the brand love construct. This study therefore provides a nuanced interpretation using such mediating roles of brand love.

Beyond its theoretical contributions, this study also provides managerial guidance for brand managers. Specifically, its findings show that brand trust is positively associated with brand love. This means that if brand managers succeed in capturing a consumer's trust in a brand, this will foster a love relationship between the consumer and that brand. Therefore, to develop brands that are loved, managers should invest in learning about consumers' desires and expectations and meet these through brand activities related to advertising and other promotion mix elements. Managers can conduct customer surveys before and after transactions. In addition, to develop a trusted brand, firms should promptly fulfil their promises and not disappoint customers. Skills and knowledge are critical in trust as well. Brand trust also contributes to consumer resistance to negative information and intention to repurchase. So, these recommendations are expected to also facilitate the process of fostering consumers' resistance to negative information and their intention to repurchase.

This study's findings provide evidence that brand love is a crucial construct in understanding consumers' attitudes and intentions. Specifically, as Fournier (1998) states, love and passion are at the centre of all consumer-brand relationships. Thus, managers should be aware of the importance of love relationships. Accordingly, they should attempt to facilitate conditions for a strong love relationship between their customers and brands. For example, they may produce products that consumers feel close to or find something that relates to their personality. Companies can design products to help consumers feel the way they want. Stylish products would be one way of meeting this goal. Batra et al. (2012) claim that if consumers believe a brand makes their life meaningful and worthwhile, they may feel love towards this brand. Participating in social responsibility projects or producing eco-friendly products would fulfil this goal. Passion is another facet of brand love (Carroll and Ahuvia, 2006). Companies may therefore focus on attractiveness, from a product's packaging to its advertising. Using celebrities in advertising would increase consumer passion for a brand. Frequency of interaction between consumers and brands is another way of creating positive consumer emotions towards brands (Patwardhan and Balasubramanian, 2011). Thus, firms can benefit from social media or e-mail to share news and the latest innovations. They may also celebrate customers' special events, such as their birthdays. Lastly, as Roberts (2005) recommends, companies should earn their customers' respect to create brand love. Quelch and Jocz (2011, p. 36) note, however, that 'the word respect rarely appears in connection with marketing', and suggest that companies can show respect for their customers by 'listening; informing; acknowledging; being truthful; treating someone with dignity, courtesy, and kindness; or not taking advantage of someone with less power" (p. 38). 
All of these suggestions facilitate brand love, leading to resistance to negative information and eventually intention to repurchase. To sum up, this study's findings have worthwhile marketing implications for firms wishing to understand the importance of brand love and its precursors and results.

\section{LIMITATIONS AND DIRECTIONS}

Brand love is said to be strongly related to products such as shoes, cars, watches, and cigarettes (Albert et al., 2008). Hence, this research model could be tested on these products. Additionally, this research focused on brands. Therefore, investigation of a particular product, store, or even service (e.g., a university) would provide further insight into brand love and other constructs. The questionnaire asked participants to specify a brand of clothing they had previously bought. It was observed that some respondents spent redundant time and effort responding to this request. Future research could therefore resolve this issue by providing a list of brands.

Resistance to negative information is a recent marketing construct. So, future research could focus on this consumer attitude. According to Pullig et al., (2006) there are two types of negative information: performance related and value related. Thus, the role of these types of negative information in consumer resistance could be examined.

Another possible avenue for future research is the investigation of the moderating role of demographic factors, such as age, gender, and income, in the relation between brand love and other variables in the research model. Thus, the role of gender in consumer brand love could be analysed.

Additionally, Vlachos and Vrechopoulos (2012) claim that the consumer trait of romanticism is related to brand love. The role of romanticism in the present model could therefore be investigated. Concerning consumer characteristics, the big five personality traits - namely openness, conscientiousness, agreeableness, extraversion, and neuroticism (McCrae and Costa, 1991) - would also be beneficial in understanding consumers' attitudes and intentions. The brand love relationship could be analysed across convenience, specialty, and shopping goods (Copeland, 1923).

\section{REFERENCES}

- Acton, V. (1998), The Role of Branding in Health Care, Managed Care Quarterly, 6(4), p.15-19.

- $\quad$ Ahluwalia, R., Burnkrant, R. E. and Unnava, H. R. (2000), Consumer response to negative publicity: The moderating role of commitment, Journal of Marketing Research, 37(2), p.203-214.

- Ahuvia, A. C. (2005), Beyond the extended self: Loved objects and consumers' identity narratives, Journal of Consumer Research, 32(1), p.171-184. 
- $\quad$ Ajzen, I. (1991), The theory of planned behaviour, Organization Behaviour and Human Decision Process, 50, p.179-211.

- $\quad$ Albert N., Boyer J., Matthews-Lefevbre, C., Merunka, D. and Valette-Florence, P. (2007), What Does Loving A Brand Really Mean? A Study of French Consumers Love Affairs, Working Paper, Colloque International de Marketing, La Londe Les Maures.

- $\quad$ Albert, N., Merunka, D. and Valette-Florence, P. (2008), When consumers love their brands: Exploring the concept and its dimensions, Journal of Business Research, 61(10), p.1062-1075.

- $\quad$ Albert, N. and Merunka, D. (2013), The role of brand love in consumer-brand relationships, Journal of Consumer Marketing, 30(3), p.258-266.

- Bagozzi, R. P., Batra, R. and Ahuvia, A. C. (2013), Brand Love: Development of an Operational Scale and Answers to Unaddressed Questions, Working Paper, University of Michigan, Ann Arbor, MI.

- Batra, R., Ahuvia, A. and Bagozzi, R. P. (2012), Brand love, Journal of Marketing 76(2), p.1-16.

- Bennett, R. (1996) Relationship formation and governance in consumer markets: transactional analysis versus the behaviourist approach, Journal of Marketing Management, 12(5), p.417-436.

- Bergkvist, L. and Bech-Larsen, T. (2010), Two studies of consequences and actionable antecedents of brand love, Journal of Brand Management, 17(7), p.504-518.

- Bhattacharya, C. B. and Sen, S. (2003), Consumer-company identification: A framework for understanding consumers' relationships with companies, Journal of Marketing, 67(2), p.76-88.

- Brown, J. J. and Reingen, P. H. (1987), Social ties and word-of-mouth referral behaviour, Journal of Consumer Research, 14(3), p.350-362.

- Carroll, B. A. and Ahuvia, A. C. (2006), Some antecedents and outcomes of brand love, Marketing Letters, 17(2), p.79-89. 
- Chatterjee, S. C. and Chaudhuri, A. (2005), Are trusted brands important?, Marketing Management Journal, 15(1).

- Chaudhuri, A. and Holbrook, M. B. (2001), The chain of effects from brand trust and brand affect to brand performance: The role of brand loyalty, The Journal of Marketing, p.81-93.

- $\quad$ Chung, I. K. and Lee, M. M. (2003), A study of influencing factors for repurchase intention in internet shopping malls, Proceedings of the Symposium on Parallel and Distributed Processing, 2003.

- $\quad$ Copeland, M. T. (1923), Relation of consumers' buying habits to marketing methods, Harvard Business Review, 1(3), p.282-289.

- Correia Loureiro, S. M. and Kaufmann, H. R. (2012), Explaining love of wine brands, Journal of Promotion Management, Vol. 18(3), p.329-343.

- Cronbach, L. J. (1951), Coefficient alpha and the internal structure of tests, Psychometrika, 16(3), p.297-334.

- Curtis, T. (2009), Customer satisfaction, loyalty, and repurchase: Meta-analytical review, and theoretical and empirical evidence of loyalty and repurchase differences, Nova Southeastern University, Lakeland, Florida.

- Delgado-Ballester, E. and Munuera-Alemán, J. L. (2001), Brand trust in the context of consumer loyalty, European Journal of Marketing, 35(11/12), p.12381258.

- Delgado-Ballester, E., Munuera-Alemán, J. L. and Yague-Guillen, M. J. (2003), Development and validation of a brand trust scale, International Journal of Market Research, 45(1), p.35-54.

- Delgado-Ballester, E. and Munuera-Alemán, J. L. (2005), Does brand trust matter to brand equity?, Journal of Product and Brand Management, 14(3), p.187-196.

- Doney, P. M. and Cannon, J. P. (1997), An examination of the nature of trust in buyer-seller relationships, Journal of Marketing, 61(2), p.35-51.

- Eisingerich, A. B., Rubera, G., Seifert, M. and Bhardwaj, G. (2011), Doing good and doing better despite negative information? The role of corporate social 
responsibility in consumer resistance to negative information, Journal of Service Research, 14(1), p.60-75.

- Elliott, R. and Yannopoulou, N. (2007), The nature of trust in brands: A psychosocial model, European Journal of Marketing, 41(9/10), p.988-998.

- $\quad$ Fang, Y. H., Chiu, C. M. and Wang, E. T. (2011), Understanding customers' satisfaction and repurchase intentions: An integration of IS success model, trust, and justice, Internet Research, 21(4), p.479-503.

- Fetscherin, M. and Conway-Dato-on, M. (2010), Brand love: Interpersonal love or parasocial love, http://www.brandmanagement.usi.ch/Abstracts/Monday/BrandrelationshipllI/Monday_Brandrelati onshipIII_Fetscherin.pdf, accessed 25 June 2014.

- $\quad$ Fischer, M., Völckner, F. and Sattler, H. (2010), How important are brands? A cross-category, cross-country study, Journal of Marketing Research, 47(5), p.823839.

- $\quad$ Fiske, S. T. (1980), Attention and weight in person perception: The impact of negative and extreme behaviour, Journal of Personality and Social Psychology, 38(6), p.889.

- Fournier, S. (1998), Consumers and their brands: Developing relationship theory in consumer research, Journal of Consumer Research, 24(4), p.343-353.

- Garbarino, E. and Johnson, M. S. (1999), The different roles of satisfaction, trust, and commitment in customer relationships, Journal of Marketing, 63(2), p.70-87.

- Grabner-Kräuter, S. and Kaluscha, E. A. (2003), Empirical research in on-line trust: A review and critical assessment, International Journal of Human-Computer Studies, 58(6), p.783-812.

- Hayes, A. F. (2009), Beyond Baron and Kenny: Statistical mediation analysis in the new millennium, Communication Monographs, 76(4), p.408-420.

- Hazan, C. and Shaver, P. (1987), Romantic love conceptualized as an attachment process, Journal of Personality and Social Psychology, 52(3), p.511. 
- Hellier, P. K., Geursen, G. M., Carr, R. A. and Rickard, J. A. (2003), Customer repurchase intention: A general structural equation model, European Journal of Marketing, 37(11/12), p.1762-1800.

- Herbst, K. C., Hannah, S. T. and Allan, D. (2013), Advertisement disclaimer speed and corporate social responsibility: "Costs" to consumer comprehension and effects on brand trust and purchase intention, Journal of Business Ethics, 117(2), p.297-311.

- Herr, P. M., Kardes, F. R. and Kim, J. (1991), Effects of word-of-mouth and product-attribute information on persuasion: An accessibility-diagnosticity perspective, Journal of Consumer Research, 17(4), p.454.

- Kamat, V. and Parulekar, A. A. (2007), Brand love - The precursor to loyalty, Advertising and Consumer Psychology: New Frontiers in Branding; Attitudes, Attachments, Relationships, p.94-95.

- Keh, H. T., Pang, J. and Peng, S. (2007), Understanding and measuring brand love. Proceedings of the Conference on Advertising and Consumer Psychology, New Frontiers in Branding: Attitudes, Attachments, and Relationships; 7-9 June 2007, Santa Monica, CA. National Bureau of Economic Research, Columbia University Press.

- Kimmel, A. J. and Audrain-Pontevia, A. F. (2010), Analysis of commercial rumors from the perspective of marketing managers: Rumor prevalence, effects, and control tactics, Journal of Marketing Communications, 16(4), p.239-253.

- Laroche, M., Habibi, M. R., Richard, M. O. and Sankaranarayanan, R. (2012), The effects of social media based brand communities on brand community markers, value creation practices, brand trust and brand loyalty, Computers in Human Behavior, 28(5), p.1755-1767.

- $\quad$ Lau, G. T. and Lee, S. H. (1999), Consumers' trust in a brand and the link to brand loyalty, Journal of Market-Focused Management 4(4), p.341-370.

- Luo, X. (2007), Consumer negative voice and firm-idiosyncratic stock returns, Journal of Marketing, 71(3), p.75-88. 
- Luo, X. (2009), Quantifying the long-term impact of negative word of mouth on cash flows and stock prices, Marketing Science, 28(1), p.148-165.

- $\quad$ Matzler, K., Grabner-Kräuter, S. and Bidmon, S. (2008), Risk aversion and brand loyalty: The mediating role of brand trust and brand affect, Journal of Product and Brand Management, 17(3), p.154-162.

- Mayer, R. C., Davis, J. H. and Schoorman, F. D. (1995), An integrative model of organizational trust, Academy of Management Review, 20(3), p.709-734.

- McAllister, D. J. (1995), Affect-and cognition-based trust as foundations for interpersonal cooperation in organizations, Academy of Management Journal, 38(1), p.24-59.

- $\quad$ McCrae, R. R. and Costa, P.T. (1991), Adding liebe und arbeit: The full five-factor model and well-being, Personality and Social Psychology Bulletin, 17(2), p.227232.

- Morgan, R. M. and Hunt, S. D. (1994), The commitment-trust theory of relationship marketing, Journal of Marketing, 58(3), p.20-38.

- Pang, J., Keh, H. T. and Peng, S. (2009), Effects of advertising strategy on consumer-brand relationships: A brand love perspective, Frontiers of Business Research in China, 3(4), p.599-620.

- Patwardhan, H. and Balasubramanian, S. K. (2011), Brand romance: A complementary approach to explain emotional attachment toward brands, Journal of Product and Brand Management, 20(4), p.297-308.

- Parasuraman, A. Zeithaml, V. A. and Malhotra, A. (2005), ES-QUAL a multipleitem scale for assessing electronic service quality, Journal of Service Research, 7(3), p.213-233.

- Pavlou, P. A. (2003), Consumer acceptance of electronic commerce: Integrating trust and risk with the technology acceptance model, International Journal of Electronic Commerce, 7(3), p.101-134.

- Pavlou, P. A. and Fygenson, M. (2006), Understanding and predicting electronic commerce adoption: An extension of the theory of planned behaviour, MIS Quarterly, p.115-143. 
- $\quad$ Preacher, K. J. and Hayes, A. F. (2008), Asymptotic and resampling strategies for assessing and comparing indirect effects in multiple mediator models, Behavior Research Methods, 40(3), p.879-891.

- Pullig, C., Netemeyer, R. G. and Biswas, A. (2006), Attitude basis, certainty, and challenge alignment: A case of negative brand publicity, Journal of the Academy of Marketing Science, 34(4), p.528-542.

- Quelch, J. A. and Jocz, K. E. (2011), Respect your customers, Leader to Leader, 2011(61), p.36-42.

- Republic of Turkey Ministry of Economy (2014), Hazır Giyim Sektörü, http://www.ibp.gov.tr/pg/sektorpdf/sanayi/hazirgiyim.pdf, accessed 25 June 2014.

- $\quad$ Roberts, K. (2005), Lovemarks: The Future Beyond Brands, New York, NY: PowerHouse Books.

- Rossiter, J. R. (2012), A new C-OAR-SE-based content-valid and predictively valid measure that distinguishes brand love from brand liking, Marketing Letters, 23(3), p.905-916.

- $\quad$ Rousseau, D. M., Sitkin, S. B., Burt, R. S. and Camerer, C. (1998), Not so different after all: A cross-discipline view of trust, Academy of Management Review, 23(3), p.393-404.

- Sarkar, A. and Murthy, B. K. (2012), Understanding and measuring romantic brand love, Journal of Customer Behaviour, 11(4), p.324-347.

- $\quad$ Shaver, P., Schwartz, J., Kirson, D. and O'connor, C. (1987), Emotion knowledge: Further exploration of a prototype approach, Journal of Personality and Social Psychology, 52(6), p.1061.

- $\quad$ Shimp, T. A. and Madden, T. J. (1988), Consumer-object relations: A conceptual framework based analogously on Sternberg's triangular theory of love, Advances in Consumer Research, 15(1), p.163-168.

- Shuv-Ami, A. (2012), The impact of love and quality on brand satisfaction and intentions, http://www.anzmac.info/conference/2011/Papers\%20by\%20Track/Track\%2004. 
\%20Consumer\%20Behaviour/Shuv-Ami,\%20Avichai\%20192.pdf, accessed 24 June 2014.

- Sichtmann, C. (2007), An analysis of antecedents and consequences of trust in a corporate brand, European Journal of Marketing, 41(9/10), p.999-1015.

- $\quad$ Skowronski, J. J., Carlston, D. E., Mae, L. and Crawford, M. T. (1998), Spontaneous trait transference: Communicators take on the qualities they describe in others, Journal of Personality and Social Psychology, 74(4), p.837.

- Sternberg, R. J. (1986), A triangular theory of love, Psychological Review, 93(2), p.119.

- $\quad$ Stone, M., Woodcock, N. and Wilson, M. (1996), Managing the change from marketing planning to customer relationship management, Long Range Planning, 29(5), p.675-683.

- $\quad$ Sung, Y. and Kim, J. (2010), Effects of brand personality on brand trust and brand affect, Psychology and Marketing, 27(7), p.639-661.

- Turgut, M. (2014), Marka Sevgisinin Marka Güveni, Olumsuz Bilgiye Karşı Direnç ve Tekrar Satın Alma Niyeti Çerçevesinde İncelenmesi, Hacettepe Üniversitesi, Sosyal Bilimler Enstitüsü, Yayınlanmamış Yüksek Lisans Tezi, Ankara.

- Turkish Statistical Institute. (2013), Hanehalkı Tüketim Harcaması, 2012, http://www.tuik.gov.tr/PreHaberBultenleri.do?id=13579, accessed 25 June 2014.

- Vlachos, P. A. and Vrechopoulos, A. P. (2012), Consumer-retailer love and attachment: Antecedents and personality moderators, Journal of Retailing and Consumer Services, 19(2), p.218-228.

- Whang, Y. O., Allen, J., Sahoury, N. and Zhang, H. (2004), Falling in love with a product: The structure of a romantic consumer-product relationship, Advances in Consumer Research, 31(1), p.320-327.

- Yasin, M. and Shamim, A. (2013), Brand Love: mediating role in purchase intentions and word-of-mouth, Journal of Business and Management, 7(2), p.101109. 
- Yoon, C., Gutchess, A. H., Feinberg, F. and Polk, T. A. (2006), A functional magnetic resonance imaging study of neural dissociations between brand and person judgments, Journal of Consumer Research, 33(1), p.31-40.

- Zboja, J. J. and Voorhees, C. M. (2006), The impact of brand trust and satisfaction on retailer repurchase intentions, Journal of Services Marketing, 20(6), p.381390. 


\section{APPENDIX 1}

Constructs and scale items

\section{Brand trust - adapted from Bagozzi et al. (2013)}

(5-point Likert scale: '1' strongly disagree and '5' strongly agree)

I trust this brand.

This brand meets my expectations.

I feel confidence in this brand.

This is a brand name that never disappoints me.

This brand name guarantees satisfaction.

If I had a complaint related to this brand or one of their products, they would be honest in addressing my concerns.

If I had a complaint related to this brand or one of their products, they would be sincere in addressing my concerns.

If I had a problem related to this brand or one of their products, I could rely on it to solve it.

This brand would make every effort to satisfy me.

If I had a problem related to this brand or one of their products, which could not readily be resolved, it would compensate me in some way for the problem.

\section{Brand Love - adapted from Bagozzi et al. (2013)}

(5-point Likert scale: '1' strongly disagree and '5' strongly agree) 
Wearing of this brand says something 'true' about who I am as a person.

Wearing of this brand says something 'deep' about who I am as a person.

This brand is an important part of how I see myself.

This brand makes me look like I want to look.

This brand makes me feel like I want to feel.

This brand does something that makes my life more meaningful.

This brand contributes something towards making my life worth living.

I find myself thinking about this brand.

I find that this brand keeps popping into my head.

I desire to wear this brand's clothing.

I am longing to wear this brand's clothing.

I have interacted with this brand in the past.

I have been involved with this brand in the past.

I am willing to spend a lot of money improving and fine-tuning a product from this brand after I buy it.

I am willing to spend a lot of time improving and fine-tuning a product from this brand after I buy it.

I feel there is a natural "fit" between this brand and I.

This brand seems to fit my own tastes perfectly.

I feel emotionally connected to this brand.

I feel I have a "bond" with this brand.

This brand is fun.

This brand is exciting.

I believe that I will be wearing this brand for a long time.

I expect that this brand will be part of my life for a long time to come.

If this brand goes out of existence, I feel anxiety.

If this brand goes out of existence, I feel apprehension.

(5-point semantic differential scale)

$\begin{array}{lllllll}\text { Negative } & 1 & 2 & 3 & 4 & 5 & \text { Positive } \\ \text { Unfavorable } & 1 & 2 & 3 & 4 & 5 & \text { Favorable }\end{array}$

Resistance to Negative Information - adapted from Eisingerich et al. (2010)

(5-point Likert scale: '1' strongly disagree and '5' Strongly agree)

Negative information about this brand does not change my general view of the brand.

Negative information about this brand has no effect on me.

Intention to Repurchase - adapted from Pavlou and Fygenson (2006) and Parasuraman et al. (2005)

(5-point Likert scale: ' 1 ' strongly disagree and ' 5 ' strongly agree)

I intend to repurchase this brand in future.

I plan to repurchase this brand in future.

I consider this brand as my first choice. 


\section{APPENDIX 2}

Reliability values, factor loadings, and explained variance values for the brand love scale

\begin{tabular}{llllllll}
\hline \multirow{2}{*}{ Items } & \multicolumn{7}{c}{ Factors } \\
\cline { 2 - 7 } & 1 & 2 & 3 & 4 & 5 & 6 \\
\hline
\end{tabular}

Life Meaning (Cronbach's Alpha: 0.88)

BL6. This brand does something that makes

my life more meaningful.

0.636

BL7. This brand contributes something towards making my life worth living.

0.609

0.803

0.786

BL9. I find that this brand keeps popping into my head.

BL14. I am willing to spend a lot of money improving and fine-tuning a product from this brand after I buy it.

BL15. I am willing to spend a lot of time improving and fine-tuning a product from this brand after I buy it.

Self-Brand Integration (Cronbach's Alpha:

0.87)

BL1. Wearing this brand says something 'true' about who I am as a person.

BL2. Wearing this brand says something 'deep' about who I am as a person.

BL3. This brand is an important part of how I see myself.

BL4. This brand makes me look like I want to look.

BL5. This brand makes me feel like I want to feel.

Long-Lasting Connection (Cronbach's Alpha: 0.81)

BL16. I feel there is a natural fit between this brand and $\mathrm{I}$.

BL17. This brand seems to fit my own tastes perfectly.

BL20. This brand is fun.

BL21. This brand is exciting

BL22. I believe that I will be wearing this brand for a long time.

BL23. I expect that this brand will be part of my life for a long time to come. 
Alpha: 0.78)

BL10. I desire to wear this brand's clothing.

0.542

APPENDIX 2: Continued...

\begin{tabular}{|c|c|c|c|c|c|c|}
\hline \multirow{2}{*}{ Items } & \multicolumn{6}{|c|}{ Factors } \\
\hline & 1 & 2 & 3 & 4 & 5 & 6 \\
\hline $\begin{array}{l}\text { BL11. I am longing to wear } \\
\text { this brand's clothing. }\end{array}$ & & & & 0.633 & & \\
\hline $\begin{array}{l}\text { BL12. I have interacted with } \\
\text { this brand in the past. }\end{array}$ & & & & 0.750 & & \\
\hline $\begin{array}{l}\text { BL13. I have been involved } \\
\text { with this brand in the past. }\end{array}$ & & & & 0.780 & & \\
\hline Anticipated Separation & & & & & & \\
\hline Distress (Cronbach's Alpha: & & & & & & \\
\hline 0.91$)$ & & & & & & \\
\hline $\begin{array}{l}\text { BL24. If this brand goes out of } \\
\text { existence, I feel anxiety. }\end{array}$ & & & & & 0.873 & \\
\hline $\begin{array}{l}\text { BL25. If this brand goes out of } \\
\text { existence, I feel apprehension. }\end{array}$ & & & & & 0.865 & \\
\hline Attitude Valence (Cronbach's & & & & & & \\
\hline Alpha: 0.75) & & & & & & \\
\hline BL26. Negative- positive & & & & & & 0.808 \\
\hline BL27. Unfavorable - favorable & & & & & & 0.847 \\
\hline Eigenvalue & 9.10 & 2.45 & 1.76 & 1.27 & 1.08 & 1.08 \\
\hline Explained Variance & $16.0 \%$ & $14.4 \%$ & $11.3 \%$ & $9,8 \%$ & $7.8 \%$ & $7.4 \%$ \\
\hline Total Explained Variance & $16.0 \%$ & $30.4 \%$ & $41.8 \%$ & $51.7 \%$ & $59.6 \%$ & $67.0 \%$ \\
\hline
\end{tabular}

